\title{
Tracing Al Shabaab's Decision to Cooperate with Al Qaeda in Somalia (2008)
}

\section{by Adlini Ilma Ghaisany Sjah}

\section{$(\mathrm{cc}) \mathrm{BY}$}

This work is licensed under a $\underline{\text { Creative Commons Attribution 3.0 License. }}$

\begin{abstract}
[1]
Al Shabaab, a Somali insurgent with predominantly nationalistic causes (alongside transnational [global Jihad] and Islamic goals) made the choice to fight on behalf of Al Qaeda in 2008. The decision to do so contrasted with Al Shabaab's previous behaviour of actively denying cooperation and distancing itself from Al Qaeda. This study aims to uncover factors that contributed to Al Shabaab's decision through the use of process-tracing. The results show that Al Shabaab's declaration of cooperation with Al Qaeda in August 2008 was brought about by a series of events that traced back to four factors: public reactions to the implementation of a Salafi ideology, the shift to a radical leadership, Al Shabaab's inability to maintain stability in areas under its control and its increasing attacks by Al Shabaab on the Somali public. Al Shabaab pursued cooperation with Al Qaeda after realizing that their nationalistic preference was no longer achievable in the near future.
\end{abstract}

Keyword(s): process-tracing, rational choice theory, preferences, nationalistic, transnational, Al Shabaab, global jihad, Somalia

$\tau$ $\mathrm{n}$ the realm of security studies, terrorists are conceived of as strategic actors that deploy a rational political strategy Crenshaw (1998). The choice to use violence is a conscious one, made by an organization for strategic and political reasons. Al Shabaab is one such actor who has shown the strategic rationale in their actions. If the assumption of Islamic ideological rationalization as the core basis of $\mathrm{Al}$ Shabaab's operations is correct, then the whole of Al Shabaab strategy should have shown Al Shabaab's complete opposition towards the West and wholehearted support to Al Qaeda's global jihad network. However Al Shabaab's history indicates otherwise. Al Shabaab initially had locally-focused operations in Mogadishu and Southern Somalia (Ploch, 2010), and were even willing to cooperate with Western humanitarian aid workers (Burton, 2010), presumably to gain local support and wealth. In 2008, one of Al Shabaab's cell commanders stated in an interview that although Al Shabaab deems Al Qaeda as brothers in Islam, there were no links between Al Shabaab and Al Qaeda (BBC, 2008). However, since August 2008, Al Shabaab has been one of the 5 main affiliate groups of Al Qaeda (Byman, 2012) and was also named by McConnell (2012) as the strongest, most dangerous, and expansive terrorist group in Sub-Sahara Africa.

This article analyzes the rational process that went into making the decision to openly declare allegiance to $\mathrm{Al}$ Qaeda. The article begins by pinpointing the critical period of change in Al Shabaab, followed by the theory and methodology employed, and lastly analyzing the factors that influenced Al Shabaab's decision making in that period. The hypothesis of this article is that Al Shabaab pursued cooperation with Al Qaeda after realizing that their nationalistic preference was no longer achievable in the near future.

Al Shabaab's initial starting point as an organization is unclear. The group's founding could be dated back to 


\section{Journal of Terrorism Research}

early 2000s as it was a descendant of the Islamic groups al Itihaad al Islamiya (AIAI) and the Union of Islamic Courts (UIC). However, Al Shabaab became a discreet collective actor in 2006, when it became the military wing of UIC. During the period of 2006-2008, Al Shabaab underwent changes that further integrated it into the global Jihad framework and, as the de facto Somali extension of Al Qaeda. There is a clear progression of changes in the organization from being the military wing of UIC, through being an independent militant organization with national ambitions to a (self-defined) 'Jihad' organization with global ambitions (see table 1).

Table 1: Al Shabaab’s Transformation (2006-2008)

\begin{tabular}{|c|c|c|}
\hline Period & Organization type & Closeness to international terrorist networks \\
\hline Jan-Dec 2006 & Military wing of UIC & $\begin{array}{l}\text { UIC publicly denounces terrorism and Al Qaeda } \\
\text { (Dagne, 2011). }\end{array}$ \\
\hline Jan - Mid 2007 & $\begin{array}{l}\text { Independent } \\
\text { organization }\end{array}$ & $\begin{array}{l}\text { Al Shabaab releases first public video, stating that } \\
\text { the enemy is the 'apostate government' (of Somalia) } \\
\text { and Ethiopian armies (Harnisch, 2011). Al Qaeda } \\
\text { approaches Somali Jihadists (not Al Shabaab in } \\
\text { particular) (Ploch, 2010). }\end{array}$ \\
\hline Mid 2007 - Feb 2008 & $\begin{array}{l}\text { Independent 'Jihad' } \\
\text { organization }\end{array}$ & $\begin{array}{l}\text { Al Shabaab shows global tendencies by repositioning } \\
\text { itself as a jihad organization in mid-2007 (Hansen, } \\
2012 \text { ), and stating that they "will move in the quest } \\
\text { for the resurrection of a worldwide caliphate[2]" (Ali, } \\
2010 \text { ). }\end{array}$ \\
\hline Feb - Aug 2008 & $\begin{array}{l}\text { Independent 'Global } \\
\text { Jihad' organization }\end{array}$ & $\begin{array}{l}\text { Al Shabaab is designated as a Foreign Terrorist } \\
\text { Organization by the United States. Al Shabaab embraces } \\
\text { its international organization status with the release } \\
\text { of "Declaration of a New 'Praiseworthy Terrorism' } \\
\text { Campaign in Response to the Tyrant America", in which } \\
\text { it rallies all foreign terrorist organizations to unite } \\
\text { against the United States and its allies. }\end{array}$ \\
\hline Aug 2008 onwards & $\begin{array}{l}\text { Self-proclaimed } \\
\text { affiliate of Al Qaeda }\end{array}$ & $\begin{array}{l}\text { Al Shabaab declares obedience to bin Laden and } \mathrm{Al} \\
\text { Qaeda with the following statement: } \\
\text { "We are now negotiating to unite as one. We will take } \\
\text { our orders from Sheik Osama Bin Laden because we } \\
\text { are his students 囚once we end the holy war in Somalia, } \\
\text { we will take it to any government that participated in } \\
\text { the fighting against Somalia or gave assistance to those } \\
\text { attacking us" (Ploch, 2010). }\end{array}$ \\
\hline
\end{tabular}

The pinnacle of the changes was the declaration of the 'New Praiseworthy Terrorism Campaign' on April $5^{\text {th }}$ 2008, where Al Shabaab stated that their enemies were no longer confined to local warlords, apostate governments, or neighbouring states, but had branched out to the United States and its alliance of 'crusaders' (Shabaab al-Mujahideen Movement, 2008). The striking thing is that in March 2008 - when Al Shabaab was designated as a Foreign Terrorist Organization (FTO) -they were still denying the existence of cooperation 
between Al Shabaab and Al Qaeda in more than one instance by Ali Mukhtar Roobow, the spokesperson of Al Shabaab, and other members (Harper, 2008). This is contradictory in nature to their goals at the time, when their appeal for help from other FTOs could have benefited from an alliance with Al Qaeda. It can be inferred that Al Shabaab's decision to cooperate with Al Qaeda could not be sufficiently explained by the evolution of its characteristics over time until April 2008. Therefore, there was a watershed moment in time when Al Shabaab decided to fully embrace the Al Qaeda mantra between late March 2008 (when Al Shabaab publicly denied cooperation) and August 2008 (when Al Shabaab publicly declared obedience to Al Qaeda and Osama bin Laden).

\section{Tracing Al Shabaab's strategic preferences}

In order to better understand this watershed moment, it's necessary first to trace the strategic preferences of Al Shabaab. In doing this, the author uses the framework of Rational Choice Theory. Rational Choice Theory assumes that actors have preferences based on their estimation of outcomes, each of which yields different levels of well-being. The rational actor chooses a particular course of action because (s)he believes it will ultimately yield the greatest amount of utility for themselves, within existing environmental constraints (Bray, 2009). In this context, utility is defined as this set of preferences, in which the higher the preference rank of a situation, the more utility it brings to the actor.

An actor's decisions rely on the value the actor places on the expected outcomes of the choices made and these valued outcomes can be material (objects) or non-material benefits (e.g., political, moral or psychological). Because an actor seeks to achieve the best possible outcome, Rational Choice Theory concludes that individuals will act in a systematic, predictable way, consistent with their preferences (Bray, 2009).

According to Anderton and Carter (2004) and Caplan (2006), the principle of rationality also exists in the mind of terrorists. Bray's explanation on individual rationality is applicable to group or organizational situations, including terrorist groups. With this approach, terrorism is indicative of collective rationality; radical political organizations become the key actor in analysis. Consistent with Bray, Crenshaw (1998) explains that organizations have a set of preferences or values and will choose to conduct terrorism when it is the best way to maximise preferences in comparison to alternative form of actions. It would follow, therefore, that Islamic militant organizations such as Al Shabaab have a set of preferences in the conditions they face, and that decisions about how to act are made to maximize their attainment of the organization's preferred outcomes.

In the case of Al Shabaab, these preferences can be derived from their historical statements and actions prior to the August 2008 since, according to Bennett and Checkel (2012), the identification of an actor's preferences for applying process tracing to rational choice theory should be performed in the periods before the outcome of the case happened. Newer preferences are given a higher rank because they are more relevant to the watershed decision we seek to explain. In other words, they are closer to the point in time when Al Shabaab made its decision to publicly declare cooperation with the transnational-jihad organisation that is Al Qaeda rather than retreat to the insular position that was its historical roots. The outcome is a set of preferences shown in Table 2. 
Table 2: Al Shabaab's rank and type of preferences

\begin{tabular}{|c|c|c|}
\hline Preferences & Type & Basis and characteristics \\
\hline 1. Conquering Somalia & Nationalistic & $\begin{array}{l}\text { Roobow's statement in August 2008, in which } \\
\text { he stated that Al Shabaab will finish the war in } \\
\text { Somalia first, then continue the struggle elsewhere } \\
\text { (Harnisch, 2010). It is also the goal most frequently } \\
\text { stated in 2006-2008. }\end{array}$ \\
\hline $\begin{array}{l}\text { 2. Successful irredentism - regaining } \\
\text { control over Muslim regions } \\
\text { conquered by Ethiopia }\end{array}$ & Nationalistic & $\begin{array}{l}\text { Objective stated in } 2003 \text { (Dagne, 2011). } \\
\text { Part of the success of the } 1^{\text {st }} \text { preference. }\end{array}$ \\
\hline $\begin{array}{l}\text { 3. Establishing an Islamic state with } \\
\text { Sharia law }\end{array}$ & Sharia & $\begin{array}{l}\text { Objective stated in } 2003 \text { (Dagne, 2011). Dependent } \\
\text { upon gaining control over Somalia. }\end{array}$ \\
\hline 4. Establishing 'Greater Somalia' & Nationalistic & $\begin{array}{l}\text { Objective stated in } 2003 \text { (Dagne, 2011). } \\
\text { Is dependent on the success of the } 1^{\text {st }} \text { preference, } \\
\text { as 'Greater Somalia' refers to the unification of } \\
\text { all regions populated by Somalis, consisting of } \\
\text { countries Somalia, Ethiopia, Kenya, and Djibouti. }\end{array}$ \\
\hline $\begin{array}{l}\text { 5. Attacking foreign targets in } \\
\text { Somalia. }\end{array}$ & Transnational & $\begin{array}{l}\text { Objective stated in } 2003 \text { (Harnisch, 2010). } \\
\text { Connected to the } 6^{\text {th }} \text { and } 7^{\text {th }} \text { preference. }\end{array}$ \\
\hline $\begin{array}{l}\text { 6. Fighting warlords supported by the } \\
\text { US in Somalia. }\end{array}$ & Transnational & $\begin{array}{l}\text { Objective stated in } 2005 \text {, yet explicitly stated to be } \\
\text { less important than conquering Somalia in the New } \\
\text { 'Praiseworthy Terrorism' Campaign in } 2008 \text {. } \\
\text { Connected to the } 5^{\text {th }} \text { and } 7^{\text {th }} \text { preference. }\end{array}$ \\
\hline $\begin{array}{l}\text { 7. Fighting third parties who assisted } \\
\text { those who attacked Somalia. }\end{array}$ & Transnational & $\begin{array}{l}\text { Objective also stated in the New Campaign in } 2008 \\
\text { to be pursued after conquering Somalia. Connected } \\
\text { to the } 5^{\text {th }} \text { and } 6^{\text {th }} \text { preference. }\end{array}$ \\
\hline $\begin{array}{l}\text { 8. Providing a safe haven for } \mathrm{Al} \\
\text { Qaeda in East Africa. }\end{array}$ & Transnational & $\begin{array}{l}\text { Objective stated in early 2000s, and was only the } \\
\text { preference of Aweys and Ayro only. Since the early } \\
2000 \text { s, this preference was never reiterated, unlike } \\
\text { all other preferences above. }\end{array}$ \\
\hline
\end{tabular}

Based on the Table 2, it can be ascertained that Al Shabaab had 3 main preferences: (1) Nationalistic, which relates to the internal struggles in Somalia, (2) Sharia, which correlated with the application of Sharia law, and (3) Transnational, which involved fighting foreign targets which were not directly related to winning the war in Somalia. This set of preferences will be further used to deduce how Al Shabaab's decision to change its stance on Al Qaeda maximized its utility at the time, in line with the framework of Rational Choice Theory. In an ideal condition, Al Shabaab's actions should cater to its nationalistic preferences first and foremost, then its sharia preferences, and finally its transnational preferences. Fulfilment of the secondary and tertiary preferences should not contradict achievement of the first preference. 


\section{Journal of Terrorism Research}

\section{Analyzing the events in April-August 2008: The losing battle for nationalistic preferences}

Having identified these preferences, it is possible to use process tracing to analyze how Al Shabaab's declaration of unification with $\mathrm{Al}$ Qaeda relates to their organizational preferences. For an ideal fit with their organizational preferences, the declaration of affiliation with Al Qaeda should have helped Al Shabaab maximize the outcomes for its primary, nationalistic preference - to conquer Somalia and establish Al Shabaab's control nationally. However, the declaration of allegiance to Al Qaeda would appear to be counterproductive in relation to the aim to achieve control over Somalia. Achieving stable control over the country requires support from the public, yet there are strong anti-foreign sentiments in the Somali society (Byman, 2012). These anti-foreign sentiments include antagonism towards Al Qaeda, caused in part by $\mathrm{Al}$ Qaeda's trademark strategy of using suicide bombing, which is considered a taboo in the Somali society. (USCIRF, 2009).Indeed, their declaration of unification with Al Qaeda would only be consistent with their organizational preferences if the following conditions would need to be met: (1) Al Shabaab had difficulties in achieving its nationalistic preference and would have achieved more utility by pursuing its transnational target, and (2) These difficulties arose in the period of March - August 2008, and (3) Al Shabaab perceived that affiliating with Al Qaeda would increase Al Shabaab's capacity to strike foreign targets. The hypothesis of this article is that $\mathrm{Al} \mathrm{Shabaab} \mathrm{pursued} \mathrm{cooperation} \mathrm{with} \mathrm{Al}$ Qaeda after realizing that their nationalistic preference was no longer achievable in the near future. In what follows, I argue that Al Shabaab was struggling to meet its nationalistic preferences due to the movement's legitimacy being increasingly questioned by the Somali public.

The support of the public is a necessity in Al Shabaab's quest to conquer Somalia; Being a small organization of only 3000-6000 members (McConnell, 2010), Al Shabaab would logically need to have public support to secure its hold on regions and the whole country. During 2006-2007, Al Shabaab initially had strong support from the public, as it was perceived to be an organization that could bring stability to Southern Somalia, and more importantly, was the only belligerent organization left in Somalia after Ethiopia's invasion which incapacitated the UIC (Wise, 2011). This support can be seen by how the communities of Jowhar and Beledweyne provided Al Shabaab with food and cooperated on security matters in mid-June 2006 (Dagne, 2011). Ali Mukhtar Roobow's public speeches on behalf of Al Shabaab in Dinsoor also received positive responses from the society in March 2007 (Reuters, 2007). However, it was reported that by the end of 2007, public support for Al Shabaab had decreased drastically in the regions it controlled (Le Sage, 2010). Local communities were distressed with Al Shabaab's style of governance, and started to form opposition towards the organization (Mulaj, 2010).

I argue that the downfall in legitimacy was brought about by 4 main reasons: (1) Al Shabaab's basic nature as a Salafi organization, (2) The change of leadership from Aden Hashi Ayro to Godane on 1 May 2008, (3) Al Shabaab's inability to maintain stability in the region in the period of March-May 2008, and (4) the increasing number of Al Shabaab attacks targeted at civilians.

Firstly, how did the Salafi character of Al Shabaab impact its operations? At first, the Salafi character of Al Shabaab did not cause problems in Somalia. However, near the end of 2008, new challenges emerged in opposition to this Salafi ideology. One of those challenges was the transformation of Ahlu Sunna wal Jamaa (ASWJ), a purely political organization prior toJuly 2008. ASWJ had militarized themselves and engaged in conflict with Al Shabaab in areas where Al Shabaab was banning Sufi religious practices (ICG, 2010) - the ideological basis of ASWJ. The Salafi ideology which proclaimed that other interpretations of Islam should be outlawed in practice caused Al Shabaab to start interdicting Sufi believers, and ban other mainstream cultural practices such as watching football matches or going to the movies because they were deemed 


\section{Journal of Terrorism Research}

"Western" (Wise, 2011). Al Shabaab's implementation of the Salafi ideology in governance was realized in mid-2008, when Al Shabaab started to directly administer the regions they controlled (Mulaj, 2010). This became a problem in Somalia, as the majority of Somali people follow the Sunni-Sufi branches of Islam(US Department of State, 2009).

This in turn caused the uproar of ASWJ members and moved them to start actively defending their Sufi communities. ASWJ was quite a big threat to Al Shabaab, as ASWJ had great access to the troops from clans' militias (Hassan, 2009), and was also reported to be receiving military support from Ethiopia (Bradbury \& Healy, 2010). In the clashes in 2008, ASWJ seemed to gain the upper hand from Al Shabaab. The presence of ASWJ in Somalia to defend Sufi communities and act against Salafi practices in general became a new source of protection for the Somali community. In contrast, Al Shabaab was becoming more and more like the enemy of the Somali society instead of the protector. The development took away Al Shabaab's initially strong legitimacy, founded in its status as the sole fighter on behalf of the Somali society at the start of 2007. Here was ASWJ, an actor that had the military capacity to provide stability but would not be restrictive in its ideology. If Al Shabaab had not been Salafi in nature and practiced these policies, ASWJ might not have militarized against Al Shabaab.

The second factor that contributed to this decision is the change of leadership in Al Shabaab. After Aden Hashi Ayro was killed by a US airstrike on 1 May 2008, the position of leader was given to Ahmed Abdi Aw-Mohamed Godane. (Westcott, 2011) Compared to Ayro who balanced nationalistic and transnational preferences quite well, Godane was a figure who was very much in favour of transnational aims and cared less about the local condition in Al Shabaab. Their difference in global jihad intentions could be seen by the public statements released during their eras. Under Ayro, Al Shabaab's statements emphasized nationalistic and anti-Ethiopian objectives. Ayro never mentioned Al Qaeda or bin Laden specifically in his speeches. However, under Godane, Al Shabaab was directly mentioned as an 'integral part of global jihad' (Kohlmann, 2009), and Godane personally declared allegiance to Osama bin Laden and other al Qaeda operatives (Horadam, 2011), before finally declaring group allegiance to bin Laden in August 2008.

With his priority on global Jihad, Godane paid much less attention to maintaining national support. This can be seen by the type of policies that Godane implemented, which usually restricted the majority of society from doing their daily habits. Godane was the prominent actor in enacting Sharia principles, even when other Al Shabaab leaders such as Roobow were against the implementation. This resulted in a significant change in public approval of Al Shabaab. In 2007, Al Shabaab was still received well by the Somali society, but in 2008, it was reported that the local society was becoming restless with how the Al Shabaab conducted governance. Thus, the Salafi basis of Al Shabaab was significantly worsened by the rise of a radical leader Godane - who implemented the Sharia law in a very strict interpretation.

These two factors by themselves were not enough to create change in Al Shabaab's legitimacy. The third factor, that is Al Shabaab's inability to maintain stability in Somalia, also played a role. With the many conflicts that happened in 2008 - both conflicts between Al Shabaab and other organizations, and also conflicts between other actors in the society - Al Shabaab's legitimacy as the bringer of stability and order (Wise, 2011) in Somalia was diminishing. Even though the reason behind Al Shabaab's failure to maintain stability was not clear, it is evident that 2008 was the year of the most intense conflict in Somalia during the last few decades a condition that is very contrary to the stability and order that was Al Shabaab's trademark.

A 4th factor that also played a role in decreasing legitimacy is how Somali people were increasingly becoming the target of Al Shabaab attacks. Based on the Global Terrorism Database, Al Shabaab's most hit target in attacks had shifted. Between October 2007 and February 2008, military personnel and location (African 


\section{Journal of Terrorism Research}

Union, Ethiopian and TFG) were the primary targets in 7 out of 9 attacks. However, between April 2008 and August 2008, private citizens and property were the most attacked, with 5 out of 12 attacks [4]. This resulted in open condemnation of Al Shabaab which could be heard in local statements in April 2008, "We condemn the artillery use on civilians, and we condemn the opposition groups who are fighting in the midst of society and using civilians as human shields" (Gilbert, 2008).

These four factors created difficult local conditions to achieve Al Shabaab's nationalistic preference. The nationalistic preference to conquer Somalia necessitated cooperation and trust from local society to be successful, especially considering existing support for other rulers in Somalia's fractured regions in South and Central Somalia, Puntland and Somaliland. In addition to the challenges of another organization, as well as the challenge towards Al Shabaab's legitimacy, made conquering Somalia a quite unreachable target.

Compared with other preferences which do not require occupation of territory (i.e. attacking foreign targets and establishing Sharia law in the regions it control), transnational goals are easier to achieve as they only require Al Shabaab to maintain attacks towards infidels such as Ethiopia and the United States. At that point, Al Shabaab was struggling to achieve transnational preferences, which is indicated by how Roobow complained of the lack of foreign fighters. However, the problem of foreign fighters is a an easier problem to deal with compared to re-establishing legitimacy in a country, as there is a global community of Mujahideen sympathetic to global Jihad causes. The Somali society, on the other hand, would be very hard to persuade as they have already experienced suffering under the governance of Al Shabaab. It was these circumstances that pushed Al Shabaab to let go of its nationalistic goals for the time being and pursue transnational preferences instead, which would boost its standing as an organization in an easier way.

\section{The benefits of declaring affiliation with Al Qaeda}

What is also clear is that publicly announcing affiliation with Al Qaeda could have been perceived to have significant benefits for Al Shabaab in terms of achieving their Sharia and transnational goals. These benefits relate to (a) battle tactics training, (b) funding, and (c) branding and recruitment.

According to Westcott (2011), there was a significant difference in the battle tactics of Al Shabaab after foreign influence, ranging from $\mathrm{Al}$ Qaeda to other foreign militant Islamist movements in Africa. Previously, the majority of Al Shabaab tactics relied on assassination (as part of an overall guerrilla strategy) when facing an enemy. However, after foreign influence, there were 2 new elements in Al Shabaab's tactics. The first is the use of suicide bombings, which up till 2006 was not known in Somalia (USCIRF, 2009). The second element is the widespread use of Improvised Explosive Devices (IEDs) and roadside bombs. Actors in Somalia had used IEDs before Al Shabaab received foreign influence and affiliated with Al Qaeda, but this method of attack became prevalent in 2010-2011, when Al Shabaab conducted 137 IED attacks in Somalia. Previous data shows that during October 2007-December 2008, there were only a total of 18 attacks using explosives/ bombs/dynamites (Global Terrorism Database, 2013).After affiliation with Al Qaeda, Al Shabaab's attacks became more coordinated, with targets of a higher profile than previously. Additionally, Al Shabaab's sniper activity to AMISOM and TFG also increased significantly (Westcott, 2011). It is logical to assume that Al Shabaab expected to receive information on combat tactics, especially on suicide bombings and IEDs as these were the dominant tactics of Al Qaeda. Moreover, one of Al Shabaab's former leaders, Sheikh Hassan Dahir Aweys, was a senior leader of AIAI (Ali, 2010), who cooperated with Al Qaeda in the 1990s and would know of this benefit.

A second perceived benefit was an increase of Al Shabaab's funding. Compared to other Jihadist 


\section{Journal of Terrorism Research}

organizations, Al Qaeda can be categorized as well-financed (Byman, 2012). Al Qaeda had access to Arab networks, and had long been sponsoring the struggle of the Egyptian Islamic Jihad (EIJ) in Egypt, Algeria's Salafist Group for Preaching and Combat (Groupe Salafiste pour la Predication et le Combat, or GSPC) in Iraq, and Chechen foreign fighters (Byman, 2012). Allying with Al Qaeda meant potentially receiving a funding benefit.

The final perceived benefit of Al Qaeda affiliation was that it would be easier for Al Shabaab to recruit foreign fighters. Ali Mukhtar Roobow has spoken about the need for more foreign fighters in the battle in Somalia, and Al Shabaab has aspired to unite the global Jihad and the Jihad in Somalia (Kohlmann, 2009). Al Shabaab's growing prominence in Islamic radical forums, in an effort to be noticed and to reach out to the international Islamic militant community can also be seen as a reason, among other interests, to recruit more foreign fighters. The declaration of affiliation with $\mathrm{Al}$ Qaeda made Al Shabaab more attractive, as supporting Al Shabaab would also be supporting the Global Jihad. Al Qaeda also had a much wider network, with the ability to reach out to various cultures and languages, which would increase the publicity of a group (Byman, 2012).This branding not only helped with recruiting, but also gave credibility to Al Shabaab and enhanced its global reputation (Byman, 2012).

Al Shabaab could confidently believe affiliation with Al Qaeda would enhance their recruitment capabilities based on their experience in February 2007. At that time, the As-Sahab Media Foundation of Al Qaeda released a video entitled "To the Army of Distress in Somalia”, in which Sheikh Abu Yahya al-Liby, acting as Al Qaeda's representative, sent a message to the Somali society to not easily surrender and give up in fighting the infidels (Kohlmann, 2009). Even though this message did not specifically identify Al Shabaab, Abu Az-Zubeyr Godane, who replaced Ayro as leader in May 2008, gave a specific thanks to Abu Yahya alLiby for helping mobilize more than 1000 mujahidin in the battle in Somalia (Kohlmann, 2009). From this experience, it can be concluded that $\mathrm{Al}$ Shabaab believed there would be positive impacts gained from $\mathrm{Al}$ Qaeda affiliation and Al Qaeda branding.

Meanwhile, recruiting more individuals in the battle in Somalia became of utmost importance in Somalia in mid 2008. Since March, Al Shabaab was experiencing attacks from the United States, firstly unsuccessfully targeting Hassan Turki (Harnisch, 2010), and Saleh Ali Saleh Nabhan (Ploch, 2010), both senior leaders of Al Shabaab. This turn of events led Roobow to conduct an interview with the Global Islamic Media Front, in which he complained that there was a lack of non-Somali 'brothers' in the battle in Somalia, and Al Shabaab has aspired to unite the global Jihad and the Jihad in Somalia (Kohlmann, 2009). In an arena of battle like Somalia, the number of troops is the most important factor, as military power indicated political significance of the organization (ICG, 2010). On the other hand, the global mujahideens who did move to Somalia were very clear about their intentions to support global jihad, and not Somali interests. One Somali who moved back to the country stated 'O' my people, know that I am not doing this martyrdom operation only for the sake of Allah and his religion...not for nationalism, tribe, and money or fame" (Kohlmann, 2009). Thus it can be seen that foreign recruitment would mostly benefit transnational causes of the Al Shabaab insurgency. However, as argued previously, at this point in time, it was a benefit that best maximized Al Shabaab's utility as nationalistic preferences would be much harder to obtain. Since the nationalistic preference of Al Shabaab was in jeopardy, pursuing global credibility would have better maximised Al Shabaab's utility. It is for this reason that $\mathrm{Al}$ Shabaab chose the path of affiliation with $\mathrm{Al}$ Qaeda to boost its organization's existence and operations for the future. 


\section{Conclusion}

This article is driven by the urgeto answer the question, "why did Al Shabaab experience a change of decision to declare cooperation with Al Qaeda in 2008?" In order to answer that question, I have used Rational Choice Theory as a framework and the model of process tracingto identify the factors that most contributed to the change of decision in August 2008.

Al Shabaab's decision to declare cooperation with Al Qaeda in 2008 was motivated by the constricting environment it faced domestically. Al Shabaab had been losing legitimacy in Somalia in the period of MarchAugust 2008, and as a result Al Shabaab had to find a way to reinvigorate its status. The most achievable way to do that was by declaring unification with Al Qaeda in August 2008, which gave Al Shabaab credibility in its commitment to global Jihad and provided Al Shabaab access to many benefits of recruitment and increased striking capacity to bolster its transnational objective. The significantly more achievable goal of gaining legitimacy internationally compared to re-establishing Al Shabaab nationally is the reason why Al Shabaab chose transnational preferences in maximizing its utility. Al Shabaab's attack in Westgate in September 2013 may be motivated by similar conditions. Only through studying Al Shabaab's preferences and conditions can we understand, and effectively counter, the actions of one of the strongest terrorist group in Sub-Sahara Africa.

About the author: Adlini Ilma Ghaisany Sjah is a research assistant and program assistant at the Department of International Relations, University of Indonesia. Her research interests include terrorism, regional security and discourse analysis.

\section{Notes}

[1] The author would like to thank Dr. Joel Busher and the anonymous reviewers for generous written comments, as well as Dr. Andi Widjajanto and Darang Sahdana Candra for their guidance and feedback.

[2] "Caliphate" is a term meaning the political-religious state comprising the Muslim community and the lands and peoples under its dominion in the centuries following the death of the Prophet Muhammad. See http://global.britannica.com/EBchecked/topic/89739/Caliphate

[3] The use of this database was further supplemented by the author's findings.

[4] In contrast, there were 4 attacks to Government and 0 attacks to military personnel and location.

\section{Bibliography}

Ali, A. A. (2010, June). The Anatomy of al Shabaab. Unpublished paper. http://www.radiodaljir.com/audio/ docs/TheAnatomyOfAlShabaab.pdf

Anderton, C. H. \& Carter, J.R. On Rational Choice Theory and the Study of Terrorism. Defence and Peace Economics, 16:4, 275-282.

Baehr, D. The Somali Shabaab Militias and Their Jihadist Networks in the West. KAS International Reports, 8 , (2011): 23 .

Barnes, C. \& Hassan, H. (2007, April). The Rise and Fall of Mogadishu's Islamic Courts. Africa Programme Briefing Paper, 07/02.

BBC: Meeting Somalia’s Islamist insurgents. (n.d.). 26 January, 2013. http://news.bbc.co.uk/2/hi/ 


\section{Journal of Terrorism Research}

africa/7365047.stm

BBC: Somalia Profile. (n.d.). 10 May, 2013. http://www.bbc.co.uk/news/world-africa-14094632.

Bennett, A \&Checkel, J.T. (2012). Process Tracing: From Philosophical Roots to Best Practices. Simons Papers in Security and Development, 21, 30.

Bradbury, M. \& Healy, S. Whose Peace is it anyway? Connecting Somali and International peacemaking. Accord, 21.

Bray, J. (2009, September). Rational Choice Models of Political Violence: The Role of Injustice and Retribution. Research Brief for the Institute for Homeland Security Solutions.

Burton, B. E. (2010). Somalia: A New Approach. Council Special Report, 52, 25.

Byman, D. L. (2012, 27 August). Breaking the Bonds between AL-Qa'ida and Its Affiliate Organizations. Analysis Paper for the Saban Center for Middle East Policy at Brookings, 27. http://www.brookings.edu/ / media/research/files/papers/2012/7/alqaida\%20terrorism\%20byman/alqaida\%20terrorism\%20byman.pdf.

Caplan, B. (2006). Terrorism: The Relevance of the Rational Choice Model. Public Choice, 128: 1/2, 91-107. Crenshaw, M. (2010, January). Mapping Terrorist Organizations. Centre for International Security and Cooperation. http://www.lps.uci.edu/files/internationalstudies/docs/crenshaw2010.pdf

Dagne, T. (2011, August). Somalia: Current Conditions and Prospects for a Lasting Peace. CRS Report for Congress.

Elmi, A. A. \& Aynte, A. Somalia: The Case for Negotiating with Al-Shabaab. Al Jazeera Centre for Studies Report.

Gartenstein-Ross, D. (2009). The Strategic Challenge of Somalia’s Al Shabaab. Middle East Quarterly, Fall, 25-35.

Gilbert, S. (2008, 20 April). 80 Dead as Somali Flush 'Sharia Courts. Yahoo News. 30 May, 2013. http://news. yahoo.com/s/nm/20080420/ts $\mathrm{nm} /$ somalia conflict dc.

Global Terrorism Database. Al Shabaab. 20 May, 2013. Start.umd.edu/gtd.

Guratna, R. (2012, May). Al-Qaeda Grows in Africa. Terrorism Risk Briefing. 19 November, 2012. https:// support.rms.com/Publikations/RMS Terrorism_Risk Briefing_May 2012.pdf

Hansen, S. J. (2012, June). The Changing Political and Security Situation in Somalia: Al-Shabaab and AlQaeda. Presented in the United Arab Emirates Counter Piracy Conference, Dubai. http://www.counterpiracy. ae/upload/Briefing/Stig\%20Jarle\%20Hansen-Essay-Eng.pdf.

Harnisch, C. (2010, 12 February). The Terror Threat from Somalia: The Internationalization of AL Shabaab. A report by The Critical Threats Project of the American Enterprise Institute.

Hassan, A. (2009, March). Inside Look at the Fighting between Al-Shabaab and Ahlu-Sunna wal-Jama. CTC Sentinel, 2:2, 5 .

Horadam, N. (n.d.). Profile: Ahmed Abdi Godane (Mukhtar Abu Zubair). 24 May, 2013. http:// www.criticalthreats.org/somalia/al-shabaab-leadership/ahmed-abdi-godane-mukhtar-abu-zubairnovember-14-2011

International Crisis Group. (2010, 18 May). Somalia's Divided Islamists. Policy Briefing Africa Briefing, 74, 13. Kohlmann, E. F. (2009). Shabaab al-Mujahideen: Migration and Jihad in the Horn of Africa. New York: NEFA 


\section{Journal of Terrorism Research}

Foundation.

Le Sage, Andre. (2010, June). Somalia’s Endless Transition: Breaking the Deadlock. Strategic Forum, No. 257. http://www.ndu.edu/inss/docuploaded/SF\%20257.pdf

McConnell, T. Al Shabaab branches out beyond Somalia. Global Post. (n.d.). 2 October, 2012. http://www. globalpost.com/dispatch/news/regions/africa/120907/al-qaeda-al-shabaab-somalia.

McConnell, T. In Africa, Al Qaeda finds new life. Global Post. (n.d.).1 October, 2012. http://www.globalpost. com/dispatch/news/regions/africa/120907/al-qaeda-africa-somalia-nigeria-mali-aqim-algeria-boko-haramal-shabaab.

Mulaj, K. (2010). Violent Non-State Actors in World Politics. New York: Columbia University Press.

Ploch, L. (2010, 3 November). Countering terrorism in East Africa: The US Response. CRS Report for Congress. 31 May 2013. http://www.fas.org/sgp/crs/terror/R41473.pdf

Shabaab al-Mujahideen Movement. Important Announcement from the General Headquarters of the Shabaab al-Mujahideen Movement: Declaration of a New 'Praiseworthy Terrorism'. Campaign in Response to the Tyrant America. 15 May, 2013. http://www.foxnews.com/projects/pdf/somaliashabaab0408.pdf

United Nations Security Council Monitoring Group (2008). Report of the Monitoring Group on Somalia pursuant to Security Council resolution 1811. Letter dated 10 December 2008 from the Chairman of the Security Council Committee established pursuant to resolution 751 (1992) concerning Somalia addressed to the President of the Security Council, S/2008/769, 18-19.

United States Commission on International Religious Freedom. (2009, 1 May). USCIRF Annual Report 2009 - The Commission's Watch List: Somalia. 30 May, 2013.http://www.refworld.org/docid/4a4f272bc.html.

United States Department of State Publication Office of the Coordinator for Counterterrorism. (2008). Country Reports on Terrorism 2008. 28 May, 2013. http://www.state.gov/documents/organization/122599.pdf United States Department of State. (2009, 25 February). 2008 Country Reports on Human Rights Practices Somalia. 22 May, 2013. http://www.refworld.org/docid/49a8f153c.html

Westcott, S. (2011). The Impact of Foreign Elements over Somalia's Al Shabaab. Thesis presented for the Honours Degree of Security, Terrorism, and Counterterrorism, Murdoch University. http:// researchrepository.murdoch.edu.au/6753/2/02Whole.pdf.

Wise, R. (2011, July). Al Shabaab. AQAM Futures Project Case Study Series, 2. 